to be performing no unfamiliar task. Many prisoners in the cell looked extremely ill, but, being entirely under Arab jurisdiction, they might die or not without Europeans becoming acquainted with the fact. The strong representations made to the Sultan by Sir John Kirk immediately he became cognisant of the facts were so far successful that this and other dens of a like description were cleared the same evening, and orders were given to have windows placed in them for ventilating purposes. Such a remedy, however, can only be palliative. The cells are incapable of proper ventilation, and the only real and effective remedy to prevent the recurrence of such scandalous barbarities is to have the fort demolished and a proper prison built in its stead. This has been strongly but unavailingly urged upon the Sultan, and nothing short of a strong expression of public opinion, combined with firm diplomatic pressure, can avail to prevent the possibility of the constant recurrence of such horrible tragedies.

Zanzibar.

\section{CASES OF SUNSTROKE WITH HIGH BODILY TEMPERATURE.}

BY T. F. O'DWYER, M.D., SURGEON MAJOR, ARMY MEDICAL DEPARTMENT.

CASE 1.-Private W. T- (Highlanders), walked to hospital on July 29th; he complained of dizziness in his head. His skin felt very hot; the pulse was quick and weak. He was stripped to the waist, and buckets of cold water were dashed over his head and back. He said he felt much better, and laughed at the idea of being carried upstairs on a stretcher. Before he arrived at the ward, however, he became insensible. His breathing was oppressed; carotids throbbed visibly ; pulse weak and quick ; pupils contracted; temperature, carefully taken in axilla, $110^{\circ} \mathrm{F}$. He was at once stripped and placed in a bath, to which large pieces of ice had been added. An icebag was placed on his head and a large piece of ice was held to his neck and back of the head. A lump of ice was placed in his mouth to melt. After being ten minutes in the bath he became conscious and looked about him, but his pulse was very weak and flickering. A dranght of aromatic spirits of ammonia was now administered. He was removed from the bath, when his temperature was found to be $105^{\circ}$. He became unconscious, and the temperature began to rise. He was again put into the cold bath. and in ten minutes the temperature of the body fell to $995^{\circ}$, and he became conscious. He was removed from the bath and an enema of sulphate of magnesia (B.P.) was administered cold. The temperature did not again rive and he made a rapid recovery, but remained weak and suffered from headache for some days.

CASE 2. - Private B- (Highlanders) was brought to hospital on July 28 th, 1883 , in a state of insensibility. Papils contracted; breathing oppressed; pulse feeble and rapid ; temperature $109^{\circ}$ in axilla. $\mathrm{He}$ was treated as in Case 1 , but his pulse became so feeble after removal from the bath that fifteen minims of sulphuric ether were administered hypodermically, and he revived at once. Temperature fell after the bath to $1006^{\circ}$, and did not rise afterwards. He made a quick recovery.

CASE 3 -Private - (Highlanders), employed in the regimental transport and much exposed to the sun, was brought to hospital on July 28 th, insensible. Temperature in axilla $108^{\circ}$; pupils contracted; heart's action weak. This patient was treated as Cases 1 and 2. Temperature reduced to $101^{\circ}$ by the cold bath, after which his pulse was oo weak that he required half an ounce of brandy and two drachms of aromatic spirit of ammonia, repeated at short intervals for three doses. He made a good recovery. These cases are typical of some that took place about the same time, and are remarkable for the high bodily temperature, the feeble condition of the heart from the same cause, and the satisfactory termination in every instance, as we were abje to deal with them at once. All took place at a time when the sun's rays were very powerful, and when cholera prevailed at Cairo.

Gitadel Station Hospital, Cairo, Aug. 1883.

THe annual prize festival in connexion with the Koyal Normal College for the Blind, Upper Norwood, was hed at the Crystal Palace on the 19th inst.

\section{LITHOTRITY AFTER BIGELOW'S METHOD.}

BY C. R. GRAHAM, L.R.C.P. ED., M.R.C.S., HON. MEDICAL OFFICER, ROYAL ALBERT EDWARD INFIRMARY, WIGAN.

MR. C-, aged sixty-two, an architect, of active and temperate habits, came under my care in private, in October, 1883. Eight years ago he passed a large quantity of minute calculi, some of the largest being about the size of a small pea. Ever since he has been troubled with frequent micturition, pain in the penis, and retention, having occasionally to seek relief from catheterisation. It was on account of this last symptom that I was at first summoned. At a subsequent examination I sounded him, detected several calculi, and also found that the prostate was enlarged, particularly the middle lobe, the sound winding to the left side immediately before passing into the bladder. This caused a little difficulty in passing the lithotrite. The urine contained a small quantity of albumen, and there was an abundant deposit of muco-pus. Operation was recommended, but the patient delayed it on account of some business engagements. In the meantime, however, he had several attacks of cystitis, causing him intense suffering and preventing sleep. His general health began to fail, and in December he was only too glad to seek relief. For a fortnight before the operation I kept the patient in-doors, and for a week prior, finding that there was a certain amount of residual urine, I passed a catheter daily. This treatment produced a marked improvement in his condition. Three days before operation the patient was confined to bed. On Dec. 20th the operation was performed; it lasted an hour and a quarter. The largest calculus was about the size of an almond. A medium-sized, non-fenestrated lithotrite was used, a No. 16 evacuator. $\mathrm{ChCl}_{3}$ was at first administered, and anæsthesia was kept up with ether. After the operation there was no reaction, and the patient suffered very little pain. About an ounce of bloody urine was passed every hour for the first day ; this gradually became clear, and micturition less frequent. On the second day after operation the urine became purulent, and the bladder was washed out daily for a week, at first with a weak solution of boracic acid, afterwards of nitric acid. The urine was especially bad on the third day, and an ounce of the decoction of couch. grass was ordered every four bours. A small quantity of detritus came away the first few days, when the bladder was in. jected. On the eighth day there was no pus in the urine, and the quantity passed in twenty-four hours varied from two to four pints. After this time he was practically well. $\mathrm{He}$ got up on the thirteenth day. With regard to diet, the first week it congisted of milk and barley water, after which he took solid food. Owing to the enlarged prostate I directed him to pass a catheter daily so that the bladder might be properly emptied, and this he continues to do. $\mathrm{He}$ is now, four months ofter the operation, in perfect health, has gained flesh, and follows his usual work. The detritus weighed between four and five drachms. The stones consisted of phosphates, with small uric acid nuclei about the size of a lentil. Of these there were four. Wigan.

\section{a) atlirror}

\section{HOS PITAL PRACTICE, BRITISH AND FOREIGN.}

Nallaantem estalia pro certo noscendi via, nisi quamplurimas et morboram ot dissectionum historias, tum aliorum tum proprias collectas habere, et

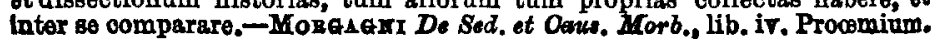

\section{GUY'S HOSPITAL.}

CASE OF CONICAL CORNEA OF BOTH EYES.

(Under the care of Mr. C. Hrgatens.)

For the following notes we are indebted to Mr. C. Y. Shuter, dresser in the eye wards :-

Caroline $\mathrm{J} \longrightarrow$, aged eighteen, was admitted on March 3rd, 1884. Three years ago she first noticed that her sight was failing, both for near and distant objects; the vision got gradually worse up to the time of admission.

On adminsion there was well-marked conical oornea in 